\title{
The Effect of Organizational Trust and Organizational Citizenship Behavior on Employee Performance
}

\author{
Yohanes Lay ${ }^{1}$, Sautma Ronni Basana ${ }^{1 *}$, and Togar Wiliater Soaloon Panjaitan ${ }^{2}$ \\ ${ }^{1}$ Department of Management, Faculty of Business and Economics, Petra Christian University, \\ Siwalankerto 121-131, Surabaya 60236, Indonesia. \\ ${ }^{2}$ School of Earth and Environmental Sciences, Queensland University, St. Lucia QLD 4057, Australia
}

\begin{abstract}
Trust given by the company to each of the employees can motivate them to contribute to the company development. Employees got to motivate themselves internally to improve their role in the organization for winning the competition. The purpose of this research is to investigate the effect of organizational trust and organizational citizenship behavior towards employee performance in Fave Hotel Rungkut Surabaya, Indonesia. Fave Hotel needs to empower the employee to improve their competitiveness. The surveys were distributed to permanent employees who have been working for at least one year. There were 52 persons who filled the surveys. The surveys used a Likert scale. The data was processed using Partial Least Square software. First, the results indicated that organizational trust affects organizational citizenship behaviors. Second, organizational trust affects company performance. Third, organizational citizenship behavior affects employee performance. Fourth, organizational citizenship as an intervening variable can improve organizational trust for employee performance. Fave Hotel commits to empower their employee through organizational trust and improves employee's role with organizational citizenship behavior.
\end{abstract}

Keywords: Company development, competitiveness, employee motiavtion, organizational citizenship behavior.

\section{Introduction}

This day, a budget hotel requires all employees to have a multitasking ability besides having a team working ability. This is required because the budget hotel requires efficiency. So, it is common to have fewer employees, and the employees have more tasks. Trust is a psychological condition of someone when someone has finally agreed to make himself serve other people because he has a positive expectation of how a thing can change [1]. Trust in an organization can be a competitive advantage for the company's internal condition which has a massive effect on a company's development. Development in a

\footnotetext{
*Corresponding author: sautma@petra.ac.id
} 
company is determined by its human resources; it can achieve its best performance if it involves human resources in its activity. OCB (Organizational Citizenship Behavior) also affects the company, especially human resources. The company needs its employee's ability, knowledge, and effort for its operational and administration activity. Human resources also improve the effectivity and efficiency of the company. A critical aspect of human resources is OCB. Performance is the result of an individual's work, both quality, and quantity, to achieve the company's purpose [2]. Teamwork is a factor that affects and improves employee's performance in the hotel. Teamwork is required in the hospitality industry [3]. This is caused because of the service industry, like the budget hotels have fewer employees, and they are required to work together. It is also required for the hotel leader. If a leader could not show his leadership, then the employee would not have OCB. This could make the leader not to be a good example for the employee. Employee's positive behavior can support individual performance and company performance for better company development [4]. Creating a good human resource is all about employee performance. If the employee works effectively, then the company will run effectively too. Performance is the result of individual work, both quality, and quantity, given the responsibility to the person itself. Performance is a result that is created as a benchmark compared to the results given.

The phenomenon in the Fave Hotel Rungkut, Surabaya, Indonesia had three variables, which were Organizational trust, Organizational citizenship behavior, dan employee performance. Fave Hotel had 50 to 55 employees. The organizational trust phenomenon has already created in the Fave Hotel Rungkut. Each employee works and builds communication with its superior and other employees. If there was a complain from the guest, the complain was done well. The trust created in Fave Hotel Rungkut also can be seen from the employee. Organizational citizenship behavior was not created directly in Fave Hotel Rungkut. Fave Hotel Rungkut was a budget hotel that required each employee to have a multitasking ability and teamwork among the other employee. This is because a budget hotel required efficiency. No wonder if employees are fewer, and some of them have a double job description. Nevertheless, everyone does their part without arguing. If the guest comes at night, the employee doesn't have any problem working longer than the day. This research defined how big is the effect of organizational trust towards organizational citizenship behavior, the effect of organizational trust towards employee performance, and the effect of organizational citizenship behavior towards employee performance.

\section{Background theory}

\subsection{Organizational trust}

Trust in an organization is one of the most important aspects of building organizational culture. Trust in an organizational can be described as three things, which are: integrity trust, character, and leadership, trust in the relationship, trust with integrity, honesty, and justice among other employees. Trust in an an organization is phycology that is contained in a condition to accept lack based on positive hope or intention from other people [1].

Employee trust toward the company can improve performance and have positive impact on another employee. Organization culture is a value that is developed in an organization, in which the value is used to direct employee behavior [5]. Employee behavior is influenced by the work environment that is created by the organization culture, where the culture is hoped to improve the company's performance. Organizational culture has the possibility to change in time, the employee can change them, and these changes of behavior have a role in creating organizational trust. There are five indicators of organizational trust, which are: integrity, competence, consistency, loyalty, and transparency [6]. 


\subsection{Organizational citizenship behavior}

Citizenship behavior is described as a volunteer activity of the employee that has the possibility to be valued or not to be valued but can contribute to the organization to improve all work [7]. Organizations in common assume that to achieve a competitive advantage, the one that is needed is the individual ability of the employee because individual work will affect teamwork. A good performance is not just based on individual ability but also based on employee behavior. The behavior required is not only in-role but also extra-role. Extra-role behavior is also called OCB. The OCB is individual behavior that is directly or indirectly acknowledged by the formal reward system and contributes to effectivity and efficiency organizational function [8]. OCB dimensions are: altruism which is a discretionary behavior from employee which help their partner in problem that can be measured by behavior; courtesy which is a discretionary behavior from employee which is over of organization's rules in case of abstention; civic virtue which is individual behavior that showing responsibility in participating with the organization; conscientiousness which is employee behavior of obeying rules, taking rest, and the base factor of company in reducing conflict; sportsmanship which is employee's willingness to tolerate unideal condition $[9,10]$.

\subsection{Employee performance}

The employee performance is a frame of employee behavior to contribute positively or negatively towards the company's purpose [7]. Employee performance is the result of employee work, which is a process of management in which the proof of the result can be shown and measurable. Employee performance is the result of the work qualitatively or quantitatively achieved by the employee [11].

The measurement of performance is important to do. The purpose of the measurement is to know whether the employee can finish his job in accordance with the time given. Performance measurement can be done to a tangible and measureable work. Therefore, it is needed to have a quantitative measurement. Performance measurement can be done to six aspects which are: result, knowledge, initiative, dexterity, behavior, dicipline in time, and absent [12].

\subsection{Relationship between concepts and research hypotheses.}

The employee can motivate themself. This is because organizational trust is a stimulus to organizational citizenship behavior significantly through employee motivated behavior [13]. In a relationship that has high organizational trust, loyality and organizational citizenship behavior can appear from the employee through contribution. The employee will volunteerly show more behavior if the employee assumes the organization where they work can be trusted. The relationship of organizational trust toward organizational citizenship behavior [14]. The result was organizational trust had a significant effect on organizational citizenship behavior. Thus:

H1: Organizational trust has a positive effect on organizational citizenship behavior in Fave Hotel Rungkut

Organizational trust effect employee performance and can build a dynamic organization environment [5]. Organizational trust as an intervening variable for ethical leadership on organization innovation with the result that organizational trust can improve organizational innovation on a public sector company in Lithuania [15]. Thus: 
H2: Organizational trust has a positive effect on employee performance in Fave Hotel Rungkut.

The effect of OCB on performance efficiency can be seen when the company can achieve its goal. The higher the OCB, the higher the performance efficiency. OCB is a behavior burdened by the company. Besides that, the higher the OCB can define how big the task and the responsibility that can be finished based on a commitment to be a better employee. With a willingness to achieve organizational goal, then this can define the efficiency of company performance [16].

Organizational citizenship behavior improves the performance in small and middle company in Bucharest, with 73 samples to SMEs (small and medium enterprises) [17]. Good relationship with a leader with building organizational citizenship behavior could affect company performance, especially in the product quality and quantity [18].

H3: Organizational citizenship behavior has a positive effect on employee performance in Fave Hotel Rungkut.

\section{Research method}

This research is descriptive quantitive research, which means that research about data collected in numbers, even if it is supported by qualitative research as supportive research. This method is called a quantitative method because the data is done in numbers and using a statistic analysis. The population is not just on the amount of object studied, but also all characteristic that is had by the object [19].

The population is an employee in Fave Hotel Rungkut, Surabaya, Indonesia which was 52 employees. The research is done to know the level of employee performance in Fave Hotel Rungkut Surabaya. The appropriate method used was descriptive quantitative research. The sample's characteristic used in this research is the respondent who qualified to answer the applied research, which was all 52 employees in Fave Hotel Rungkut called by saturated population. The data collection method is through a questionnaire. The questionnaire is a data collection technique where the respondent fill the survey completely.

The analysis technique used in this research is a quantitative analysis using the SEM model with smartPLS software version 2.0. SEM can test the direct and indirect effects on variables [20]. Sem is a statistic technique to test and estimate the causal relationship with integration factor analysis and path analysis. Pls is one of analysis method based on variance designed to finish a multiple regression when a specific problem on data occur, as the small amount of research sample model evaluation in pls done with evaluating the outer model and inner model. The first outer model test is the construct validity test to show how good the result was to describe a construct. A strong correlation between construct and indicators is more than 0.5 . validity test was done, and the result was a lot of indicators has a value under 0.5 . This can cause an invalid process, so some items had to be deleted which are: do things according to words (X13) with factor loading of 0.499 ; not misusing other people rights (X24) with factor loading of 0.387 ; try to avoid problem (X25) with factor loading of 0.436; realizing the impact of work (X26) with loading factor of 0.259 ; avoid problem when working (X27) with factor loading of 0.471 ; produce performance that exceed standard (X28) with loading factor of 0.241 ; and not blaming other people of selfmistake (Y17) with loading factor of 0.379 . The second stage had all meet the requirements of more than 0.5 (table 1 ).

Outer model test result composite reliability is rated good if the value is more than 0.7. Composite reliability for organization trust is 0.862 ; organization citizenship behavior 0.858 ; employee performance 0.824 . each variable had the composite reliability of more than 0.7 , which means it can be concluded that the reliability met the requirement. 
Table 1. Convergent Validity Test

\begin{tabular}{|c|l|l|c|}
\hline \multicolumn{3}{|c|}{ Variable } & \multicolumn{3}{|c|}{ Measurement item } & Loading factor \\
\hline \multirow{5}{*}{$\begin{array}{c}\text { Organization Trust } \\
\text { (X1) }\end{array}$} & X1.1 & Honest working & 0.755 \\
\cline { 2 - 4 } & X1.2 & Work seriously & 0.703 \\
\cline { 2 - 4 } & X1.4 & Keeping promises to a colleague & 0.603 \\
\cline { 2 - 4 } & X1.5 & Sharing ability & 0.543 \\
\cline { 2 - 4 } & X1.6 & Developing self-ability & 0.724 \\
\cline { 2 - 4 } & X1.7 & Obeying company rules & 0.607 \\
\cline { 2 - 4 } & X1.8 & Honest to colleague & 0.522 \\
\cline { 2 - 4 } & X1.9 & Work with enthusiasm & 0.641 \\
\cline { 2 - 4 } & X1.10 & Transparency toward company & 0.630 \\
\hline \multirow{5}{*}{$\begin{array}{c}\text { Organization Citizenship } \\
\text { Behaviour }\end{array}$} & X2.1 & Helping absent colleague & 0.657 \\
\cline { 2 - 4 } & X2.2 & Helping a busy colleague & 0.569 \\
\cline { 2 - 4 } & X2.3 & Voluntarily helping colleague & 0.716 \\
\cline { 2 - 4 } & X2.9 & Keeping a relationship with a & 0.633 \\
\cline { 2 - 4 } & & colleague & 0.634 \\
\cline { 2 - 4 } & X2.10 & Not much whining the company & 0.616 \\
\cline { 2 - 4 } & X2.11 & Not looking for a company mistake & 0.715 \\
\cline { 2 - 4 } & X2.12 & Focus on positive things & 0.777 \\
\hline \multirow{5}{*}{$\begin{array}{c}\text { Employee Performance } \\
\text { (Y) }\end{array}$} & Y1.1 & Understanding the work & 0.658 \\
\cline { 2 - 4 } & Y1.2 & Can work exceeding the standard & 0.618 \\
\cline { 2 - 4 } & Y1.3 & Can work with the time given & 0.658 \\
\cline { 2 - 4 } & Y1.4 & Producing an expected result & 0.555 \\
\cline { 2 - 4 } & Y1.5 & Doing the work right & 0.670 \\
\cline { 2 - 4 } & Y1.6 & Willing to do the work until finished & \\
\hline
\end{tabular}

\section{Analysis and discussion}

The inner model is a structural model to predict the causal relationship between latent variable. Through the bootstrapping process, a t-statistic parameter test was obtained to predict the causality relationship. The causal relationships developed in the model needs to be tested with the null hypothesis. This hypothesis declared that the regression coefficient between the relationship is not different from null through t test like in the regression analysis. Hypothesis test in this research is done with an inner model test, which is an exogen latent variable on endogen and endogen latent variable to endogen variable. Hypothesis using $5 \%$ alpha with the t-test used is 1.96 , so the hypothesis will be refused if the t-test value is below 1.96. The result of data analysis for hypothesis test is in Table 2.

Table 2. Results Inner Model for Hypothesis Test

\begin{tabular}{|c|c|c|c|c|}
\hline Effect of Variable & $\begin{array}{c}\text { Original sample } \\
\text { estimate }\end{array}$ & $\begin{array}{c}\text { Mean of } \\
\text { subsamples }\end{array}$ & Standart deviation & t-statistic \\
\hline $\mathrm{X}_{1}->\mathrm{X}_{2}$ & 0.741 & 0.747 & 0.029 & 5.824 \\
\hline $\mathrm{X}_{1}->\mathrm{Y}_{1}$ & 0.508 & 0.501 & 0.082 & 6.211 \\
\hline $\mathrm{X}_{2}->\mathrm{Y}_{1}$ & 0.303 & 0.313 & 0.079 & 3.848 \\
\hline
\end{tabular}

Organizational trust in organizational citizenship behavior had a gamma coefficient of 0.741 and a t-statistic of $5.824>1.96$. that means organizational trust has a positive effect on organizational citizenship behavior in Fave Hotel Rungkut. This can be seen from the mean value of the survey that showed a value of more than 4.2 and was categorized as high. The mean result of variable organizational citizenship behavior also showed a value of more than 3.4 with a high category. This result is in line with the fact that showed the Fave 
Hotel Rungkut keeps on building a better organization trust. The mean result of organizational trust shows the highest indicator is loyalty in the item x19 which is working honestly and developing self-ability. This shows that when the employee works with enthusiasm, then the employee shows a sense of trust to the company through good behavior.

Organizational trust in employee performance based on table 2, coefficient gamma is 0.508 , with a t-statistic of $6.211>1.96$. The result shows that $\mathrm{H} 2$ is accepted. This means that organizational trust has a positive effect on employee performance in Fave Hotel Rungkut. Statistic result shows that employee performance in Fave Hotel Rungkut can be categorized as high. This can be seen from the mean value of 4.2 and categorized as high. The mean result of variable employee performance also shows 3.4 value and categorized as good. The result is in line with the fact that show Fave Hotel Rungkut employees keep on carrying out the task with the time given to them. This can be created through the application of clear job description. The mean result of variable employee performance shows the highest indicator is quantity, which is on item y13, which is doing the task on schedule. This finding also supported by the previous research that organizational trust affects employee performance [21].

Organizational citizenship behavior on employee performance based on Table 2 has the gamma coefficient of 0.303 with a t-statistic of $3.848>1.96$. The results showed that $\mathrm{H} 3$ was accepted. Thus, organizational citizenship behavior has a positive effect on employee performance in Fave Hotel Rungkut. Statistic results showed that organizational citizenship behavior in Fave Hotel Rungkut could be categorized as high. This can be seen from the mean value of over 4.19 and categorized as high. The finding was in line with the fact that in Fave Hotel Rungkut, employees appreciate every right the company gave to the employee, so a high organization citizenship behavior can be created. The highest indicator was item X23, which was a volunteer in helping other employees in their job.

\section{Conclusion}

Based on the research result, this research can be concluded that organizational trust has a positive effect on organizational citizenship behavior in Fave Hotel Rungkut, with working honestly and developing self-skill to inspire other employees in their job. Organizational trust has a positive effect on employee performance in the Fave Hotel Rungkut with working honestly and developing self-skill to inspire other employees can improve the knowledge of the job. Organization citizenship behavior in the Fave Hotel Rungkut voluntarily helps other employees in their job and focusing on the hotel goal. Also, positive things for the hotel can give knowledge for the employee and improving their skills in finishing the job.

\section{References}

1. F.N. Koranteng, I. Wiafe, F.A. Katsriku, R. Apau, Applied Computing and Informatics, 2019:1-9(2019). https://doi.org/10.1016/j.aci.2019.07.003

2. R. Kao, Personnel Review, 46,46:718-739(2017). https://doi.org/10.1108/PR-08$\underline{2015-0234}$

3. A.C. Lakoy, Jurnal EMBA, 3,3:981-991(2015). [in Bahasa Indonesia]. https://ejournal.unsrat.ac.id/index.php/emba/article/view/9773

4. M. Asrar-ul-Haq, K.P. Kuchinke, Future Business Journal, 2,1:54-64(2016). https://www.sciencedirect.com/science/article/pii/S2314721016300032 
5. S. Brown, D. Gray, J. McHardy, K. Taylor, Journal of Economics Behavior \& Organization, 116:361-378(2015).

https://www.sciencedirect.com/science/article/pii/S0167268115001365

6. S.P. Robbins, T.A. Jugde, Perilaku perusahaan. [Company behavior]. Jakarta: Salemba Empat (2008). [in Bahasa Indonesia]. http://36.67.167.42:8123/inlislite3/opac/detail-opac?id=25729

7. J.A. Colquitt, J.A. LePine, M.J. Wesson, Organization behavior: Improving performance and commitment in the workplace. New York: McGraw-Hill(2009). http://www.semesteratsea.org/wp-content/uploads/2015/03/Trittipo_SEMS3500_Organizational-Behavior5.pdf

8. H.K. Iqbal, U. Aziz, A. World Applied Sciences Journal, 19,9:1348-1354(2012). https://pdfs.semanticscholar.org/27f9/80af9ef4e60f53dcdd89675f5b10d01ad651.pdf

9. P. Agarwal, International Journal of Organizational Analysis, 24,5:956-984(2016). https://doi.org/10.1108/IJOA-12-2014-0826

10. D.W. Organ, P.M. Podsakoff, S.B. MacKenzie, Organizational citizenship behavior: Its nature, antecedents and consequences. USA: Sage Publications, Inc(2006). http://sk.sagepub.com/books/organizational-citizenship-behavior

11. M.R Dehaghi, A. Rouhani, Procedia-Social and Behavioral Sciences, 141:903908(2014). https://www.sciencedirect.com/science/article/pii/S1877042814035824

12. L.I. Syafii, A. Thoyib, U. Nimran, Djumahir. Procedia-Social and Behavioral Sciences 211:1142-1147(2015). https://www.sciencedirect.com/science/article/pii/S1877042815054920

13. D. Yoon, J. Jang, J. Lee, International Journal of Contemporary Hospitality Management, 28,8:1577-1597(2016). https://www.emeraldinsight.com/doi/abs/10.1108/IJCHM-10-2014-0498

14. S. Altuntas, U. Baykal, Journal of Nursing Scholarship, 42,2:186-194(2010). https://sigmapubs.onlinelibrary.wiley.com/doi/abs/10.1111/j.1547-5069.2010.01347.x

15. R. Pučètaitè, Procedia-Social and Behavioral Sciences, 156:231-235(2014). https://www.sciencedirect.com/science/article/pii/S1877042814060005

16. C-C. Chang, M-C. Tsai, M-S. Tsai, International Journal of Trade, Economics and Finance, 2,1:61-66(2011). http://www.academia.edu/download/35672659/31.pdf

17. A.M. Popescu, A. Deaconu, T. Popescu, Procedia Economics and Finance 22:645654(2015). https://www.sciencedirect.com/science/article/pii/S2212567115002786

18. C-C.L. Tai, C-M. Chang, J-Y. Hong, and L-C. Chen, Procedia-Social and Behavioral Sciences, 57:511-517(2012). https://www.sciencedirect.com/science/article/pii/S1877042812046800

19. Sugiyono, Metode penelitian pendidikan pendekatan kuantitatif, kualitatif, dan $R \& D$. [Educational research methods in quantitative, qualitative and $R \& D$ approaches].

Bandung: Alfabeta (2017). [in Bahasa Indonesia]. https://books.google.co.id/books?id=0xmCnQAACAAJ

20. S. Bahri, F. Zamzam, Model penelitian kuantitatif berbasis SEM-AMOS. [Quantitative research model based on SEM-AMOS]. Yogyakarta: Deepublish(2014). [in Bahasa Indonesia]. https://books.google.co.id/books?id=1OXoCAAAQBAJ\&printsec=frontcover

21. P.G. Fard, F. Karimi, International Education Studies, 8,11:219-227(2015). https://eric.ed.gov/?id=EJ1082147 